\title{
Mesztegnyő középkori településszerkezetének változása
}

\author{
ARADI CSILLA \\ KJH, Járási Építésügyi és Örökségvédelmi Hivatal \\ H-7400 Kaposvár, Csokonai u. 3., csiaradi@freemail.hu
}

Aradi, Cs.: The changes of medieval settlement structure in Mesztegnyö

Abstract: The paper deals with the changes in settlement structure of Mesztegnyő, a medieval town situated in InnerSomogy, between the Sári and the Boronka brooks, on the Eastern slopes of the Marcali hills.

Keywords: oppidum, Dominican closter, population change, fortification, street network, land division

\section{Természeti adottságok, a középkori településre vonatkozó írásos adatok}

Mesztegnyő ma Belső-Somogyban, a Marcali-hát keleti oldalának lankás dombjain, a Sári-víz, a Malom-árok és a Boronkai-patak fűzérszerű halastórendszere által határolt területen, Marcalitól 10 kilométerre délre terül el. A középkorban Marcalin át Somogyvárral, délre pedig Nagyatádon és Babócsán át Verőcével állt összeköttetésben.

Első ízben 1329-ben, a dencsi malom eladása ügyében hallunk a faluról ${ }^{1}$, bár feltehetően már korábban is létezett, mivel a 15. században már oppidumként említik a települést. 1466-ban már országos vásártartási joggal is rendelkezett. ${ }^{2}$ A mezőváros a 14. században a Mesztegnyői Szerecseneké volt, azonban Zsigmond a birtokot hűtlenség miatt elkobozta és a Gordovai Fancsoknak adományozta. A birtoklás megváltoztatására a Szerecsen család még a 15. század második felében is tett kísérletet.

A segesdi föesperesség alá tartozó plébánia papja, Domonkos 1333-ban 66 kis dénárt, 1334-ben 5 garast fizetett. ${ }^{3}$ 1359-ben két ízben is említik Tamás mesztegnyői papot és balatonszögi (de angulo Balatin) esperest. ${ }^{4}$ A balatonszögi esperesség (vicaria) területe a Balaton-Segesd vonal mentén húzódott a Marcali-hát nyugati oldalán, Szakácsi és Tapsony falvakon át, másik oldalát a somogyvár-segesdi út képezte, és Pusztakovácsi, valamint Somogyfajsz érintésével a Marcali-hát keleti oldalán haladt. Ennek lehetett ekkor központja Mesztegnyő. 1401-ben a mesztegnyői Szent Miklós-egyház kaszálójával találkozunk a forrásokban, amelynek szomszédjában a Szakácsiak vesznek rétet. ${ }^{5}$ 1429. február 4-én Györgyről és Jánosról, a Szent Miklós-parochia papjairól értesülünk. ${ }^{6}$ 1436-ban is hallunk a mesztegnyői vicariatusról. ${ }^{7}$ 1476. augusztus 16-án Szentey György supplicatiójára érkezik a pápai engedély, miszerint a domonkosok számára Mesztegnyőben házat kíván alapítani, és ennek egyesítését kéri a Szent Miklós-plébániatemplommal, amelynek kegyura. A plébániához tartozó javadalmakat is megkapná a kolostor, ugyanakkor a hívek gondozását az egyik frater kötelessége lenne ellátni („,applicare necnon priori eiusdem domus... ut curam eorundem parochianorum... per unum ex fratribus... exerci facere possit"). ${ }^{8}$ A plébániatemplom alkalmas a szerzetesi funkciók betöltésére is, mivel kellő birtokkal rendelkezik „cum campana, campanili orto”. Úgy látszik, a plébánia mégis tovább működött, hiszen 1500-ban Gergely plébános nevével találkozunk, sőt a plébánia még 1546-ban is fennállt. ${ }^{9}$ 1555-ben Nádasdy Tamás a kolostort az erődített helyek között említi. 1558-ban az erődítés már török kézen volt, melyről Zrínyi Miklós Nádasdy Tamásnak írott levelében beszámol, eszerint a török Pécsett gyülekezik, Babócsát akarja megtámadni vagy a mesztegnyői zárdát megerősíteni (monasterium meztene munire). ${ }^{10}$ Ugyanebben az évben az erődítés elkészültéről számol be Csányi Ákos tiszttartónak Orosztonyi Péter Szenyérből írott levelében: „Mesztegnyőnek a kapuját is megcsinálták, készen vagyon, az Mesztegnyő egy olyan ház, hogy csak egy kapu héja vagyon, a többi

1 Borsa 1996. 66. DF 230321

2 Nundine in opido Meztegnew. A településen ekkor 63 jobbágycsalád lakott. Bándi 1986. 57. DL 18312, Csánki 1894. 57. 9., Borovszky - Csánki 1914. 109., Kubinyi 1989. 330. Évi vásárát június 29-én tartották. DL 86398

3 Mon. Rom. II. 67., 75.

4 Bándi 1986. 28. DL 4867

5 ZSO II. 131., Bándi 1986. 34. DL 8659

6 Lukcsics 1938. 216.

7 Békefi 1907. 105.

8 Harsányi 1938. 86. „parochialis ecclesia S. Nicolai dicti oppidi, qui de iure patronatus prefati comitis (Szentey) existit et per rectorem seu capellanum ad nutum..."

9 Békefi 1907. 105., Kanyar 1991. 135

10 Vizy 2012. 
mind épen vagyon, ezért kegyelmed gondoljon reá, hánnyák el, kellene népet indítani reá, rúddal, doronggal el nem terhetik, por (lőpor) kellene hozzá." 1542-ben a település 18 adózó portával bírt, azonban 1557-re már teljesen elhagyatottként írták össze. ${ }^{11}$

\section{Helyzetkép a hódoltság után, a település kiterjedésének változásai}

A török után a település csak lassan népesedett be, 1702-ben 16 adózó, 1720-ban 12 család lakta a 96 köböl szántóval, 25 kaszás réttel és 26 köböl elhagyott szántóval, malommal rendelkező falut. Úgy tűnik, ekkor még bővében voltak a földeknek. A Mária Terézia-kori úrbérrendezés 47 adózó családról ad számot, melyek közül 24 helyi, 23 pedig bevándorló. Az összlakosságszám a 42 házban 285 főt tett ki. A 47 adózó (32 telkes gazda, 12 házas zsellér, 3 házatlan zsellér) 20 és $1 / 2$ telken gazdálkodott, tehát a telekaprózódás már ekkor elkezdődött. ${ }^{12}$

A változások a majorsági uradalom kialakulásával folytatódtak, mivel a korábbi jobbágytelkekhez tartozó külsőségekből mind nagyobb terület került az uradalom gondozásába. ${ }^{13}$ Ugyanakkor a birtokos a tudatos betelepítések révén növelte a majorsági birtokon dolgozók létszámát. 1771-ben a földesúri irtásföldekből 38 új telket alakított ki, ahová 58 családot telepített. Az 1784-85-ös összeírás szerint Mesztegnyő 90 házból állt és 126 család lakta, a férfiak közül pedig 13 pap (ekkor még a ferences szerzetesekkel együtt) valamint 14 nemes, 51 paraszt és 53 zsellér volt. 1789-ben 590 föből állt a település, míg 1820-ban 82 házban még mindig csak 630 fő lakott. ${ }^{14}$ Az uradalmi központ eddigre már kiépült, külön házzal bírt az erdőmester, a fiskális, volt vadászház, pálinkaház, mészárszék, épültek béres házak, és létesült méhes, (tekenyőbékás) tó. A majorsági épületek egy része a háromszög alakú főtér (Szabadság tér) területén (magtár, gémes kút) állt, míg más része a Pajtáskert nevű dűlőben foglalt helyet, melynek nevét az itt álló pajtákról nyerte. A Klastrom kertben tölgyfapalánkkal védett gyümölcsöst telepítettek. A településen élő kézművesek a hagyományos foglalkozások köréből kerültek ki (bognár, kovács, molnár, takács, mészáros, kocsmáros). Az l. katonai felmérés tanúsága szerint a kőfallal övezett, kőből (téglából) épült kolostor, a kocsma, gazdasági épületek, a tisztviselőház, a falutól kis távolságban lévő erdészház, a gulya őrzésére szolgáló ún. Sweizerhaus illetve a Kopár vendéglő számítottak jelentős épületeknek.

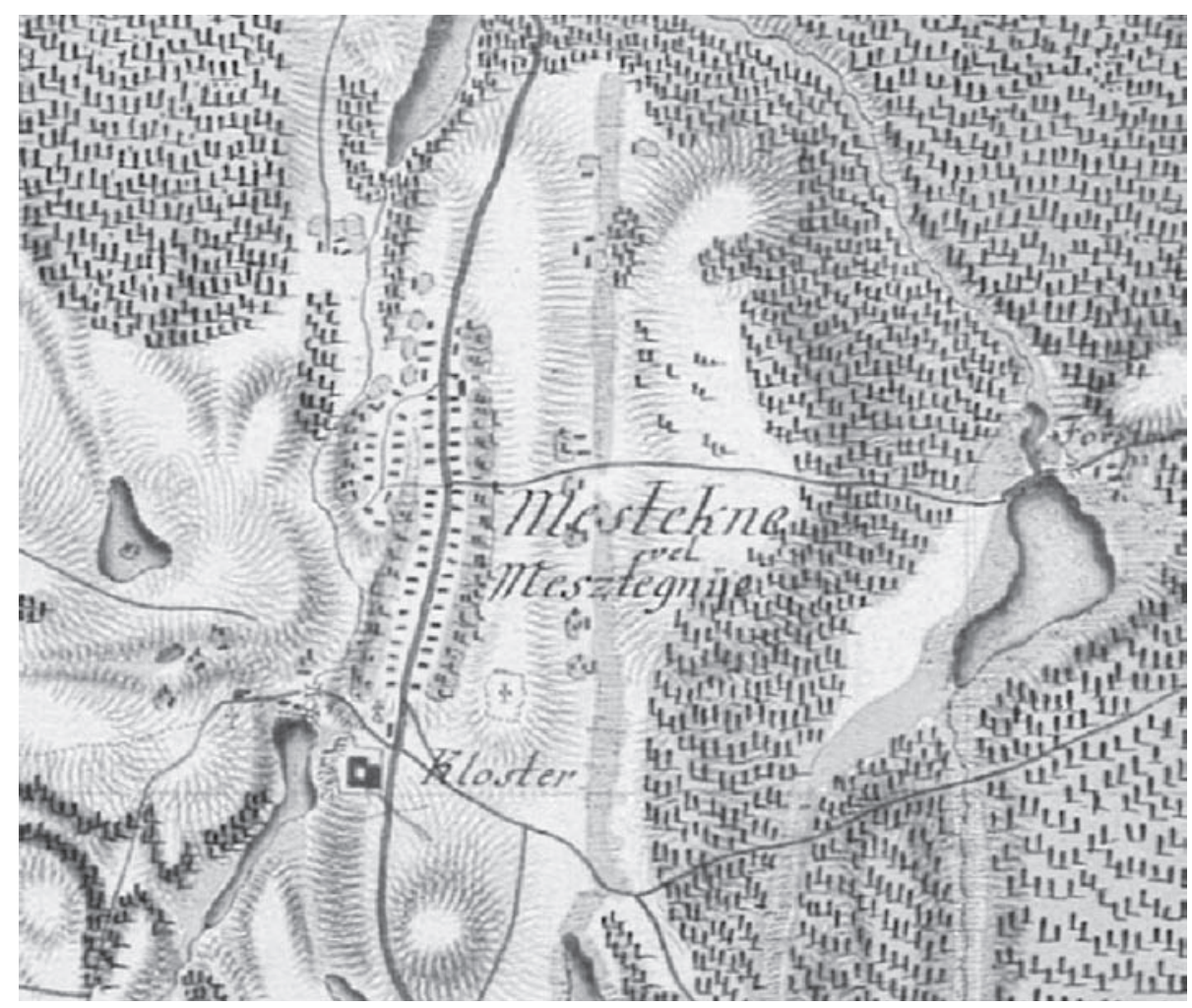

1. kép: Mesztegnyő az I. katonai felmérés szerint

11 G. Jáger 2007.

12 G. Jáger 2007.

13 Míg 1767-ben még nagy telken kívüli állománnyal bírtak a jobbágyok (összesen 868 pozsonyi mérő szántó), addig 1828-ra ez a szám már elenyésző (1911/2 pozsonyi mérő) volt. Hasonlóképpen csökkent a rét területe (100-ról 24-re).

14 G. Jáger 2007. 
Egy 1815. évi egyházlátogatási jegyzőkönyv az 1740-ben alapított iskolaépületről ad leírást: „talpakra épített, fonyásból sározva, egy szobából, egy füstös konyhából, egy kamrából állt a hozzá épült egy szoba méretü düledező oskola."15 Ennek alapján feltételezhetjük, hogy még mindig a talpas házak alkották az épületállomány zömét. Az 1820-30-as években cseh (morva) betelepítéssel újonnan nőtt a népességszám, eszerint az „Ó utca napnyugatra fekvő alsó részén 20, a templom átellenében pedig 50 ház épült, s így a népesség ötszázról ezerig rúgott fel." A forrás alapján ekkor alakult ki a Szabadság tér nyugati oldala és nyitották meg a Cseh utcát (mai nevén Ladi János utcát). A II. katonai felmérés már ezt az állapotot ábrázolja. A betelepítések ellen a határ szűkössége miatt a korábbi jobbágyok szót emeltek: „Kisded határunkat a földesuraságunk 78 zsellér lakossal és házzal terhelte meg... régi irtásföldjeinktöl fizetés nélkül megfosztott, hogy alig-alig lebeghetünk." ${ }^{\prime 6} \mathrm{Az} 1859$-es kataszteri térkép tanúsága alapján a betelepítés még később is folyt, a belterület északkeleti részén Hunyadi József cigánylakásokat létesített. 1846 és 1883 között a földesúri birtok aránya 67 \%-os növekedést mutatott. A 20. század elején jött létre a mai Hunyadi és Béke u. (Egysoros, Kétsoros), az 1950-es években pedig a későbbi Ady Endre, József Attila, Dózsa György, Petőfi Sándor, Táncsics Mihály utcák mellett a Pajtáskert területén a Kossuth Lajos utca.
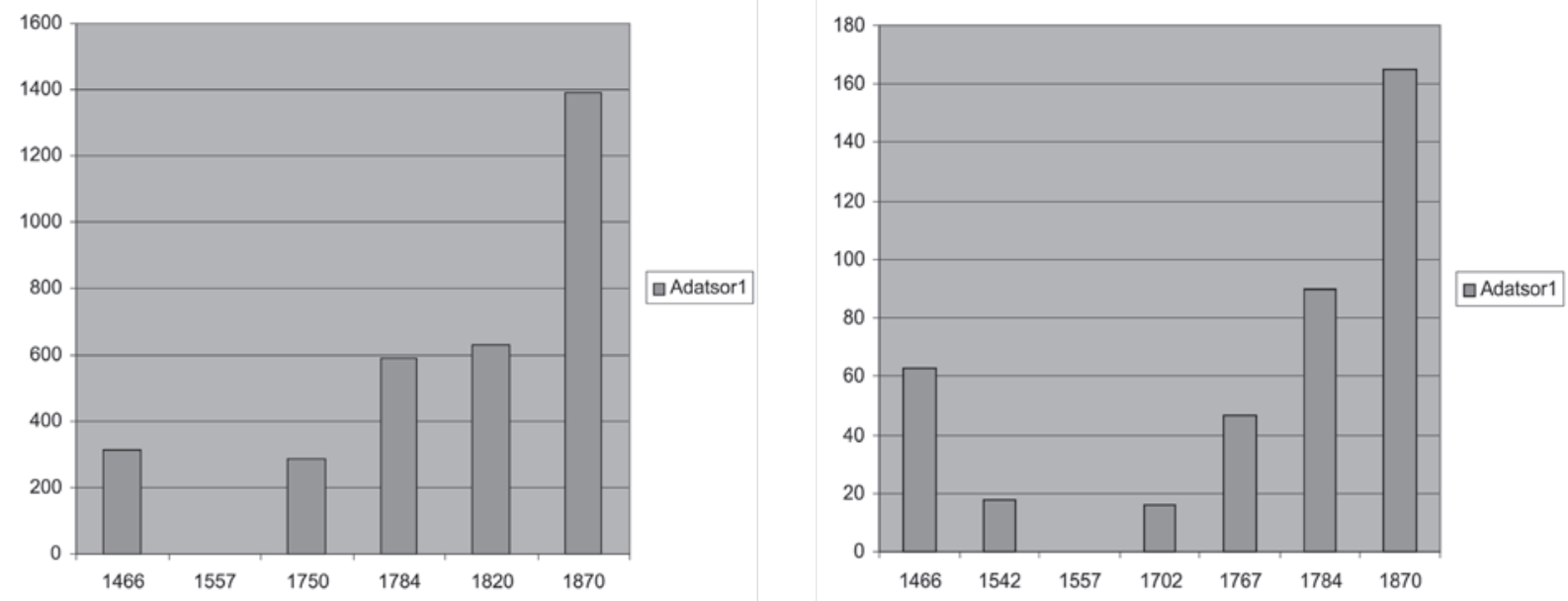

2. kép: Lakosságszám és porták/házak számarányának változásai

A fenti adatok is világossá teszik, hogy a középkori oppidum lakosságszámát és portáinak számát csak a 18. század második felére éri utol a település, ugyanakkor látványos számbeli fejlődés csak a 19. század közepétől következik be. A 19. század eleje és második fele között - leginkább a betelepítéseknek köszönhetően - a lakosság száma megduplázódott, és ha nem is ilyen arányban, de a porták száma is jelentős emelkedésnek indult (Id. új utcák nyitása).

\section{Mesztegnyő egyházi emlékei}

1733-ban vásárolta meg a Hunyadi család a kéthelyi uradalmat Harrach Rajmund gróftól, melynek Mesztegnyő is részét képezte. ${ }^{17} \mathrm{Az} 1743$-as egyházlátogatás során két romos templomot említenek, ezek közül az egyik a településen kívül álló kolostortemplom volt, amelynek teteje már hiányzott, de jó állapotban maradt meg falazott tornya, illetve még helyreállítható, quadrumban épült tetőzet nélküli kolostorral bírt. A plébániatemplom az előzőtól puskalövésnyire állt romos állapotban. ${ }^{18} 1712-42$ között Vörös Gergely nős licenciátus látta el a hívek lelki gondozását. Ekkor épült a falu központjában, a licenciátus házával egy fedél alatt az a szentély és sekrestye nélküli, sövényből font, sárral tapasztott, szalmával fedett oratórium, melyet az l. katonai felmérés is ábrázol. Az udvaron fa harangláb állt. 1744-ben Hunyadi István halála után, Hunyadi Antal, elődjéhez hasonló feltételek mellett alapított ferences zárdát Nepomuki Szent János tiszteletére a településen, amely 1790-ig élt

15 A ma is álló épületet 1838-ban emelték, jelenleg itt tekinthető meg a honismereti gyűjtemény. Az újabban épült plébánia már komfortosabb lehetett, a cselédszobával együtt 3 szobás, kamrával, bolthajtásos pincével, kéményes konyhával ellátott épület, amelynek udvarán zsuppal fedett istálló is helyet kapott.

16 G. Jáger 2007.

17 Bár a Hunyadi család a Gordovai Fancs családdal rokonságot tartott fenn, a birtokhoz örökléssel mégsem jutott. A 18. század végére a birtoktest központja Sáripuszta lett.

18 A két templom a falutól 1/4 Óra járásnyira helyezkedett el. Lángi 1995. 229., Romhányi 2000. 43. 
tovább (az építkezéshez a középkori templom tégláit is felhasználták). ${ }^{19} \mathrm{Az} 1778$-ig elhúzódó építkezéseket Antal fia János fejezte be. Az 1748-as Canonica Visitatio szerint „még áll a régi templom egy része (ti. a Vörös Gergely féle), amelyben az új templom befejezéséig tartják az istentiszteletet. A régi templom fedele szalmából készült, szószéke és paraszti munkával készült padjai vannak."20
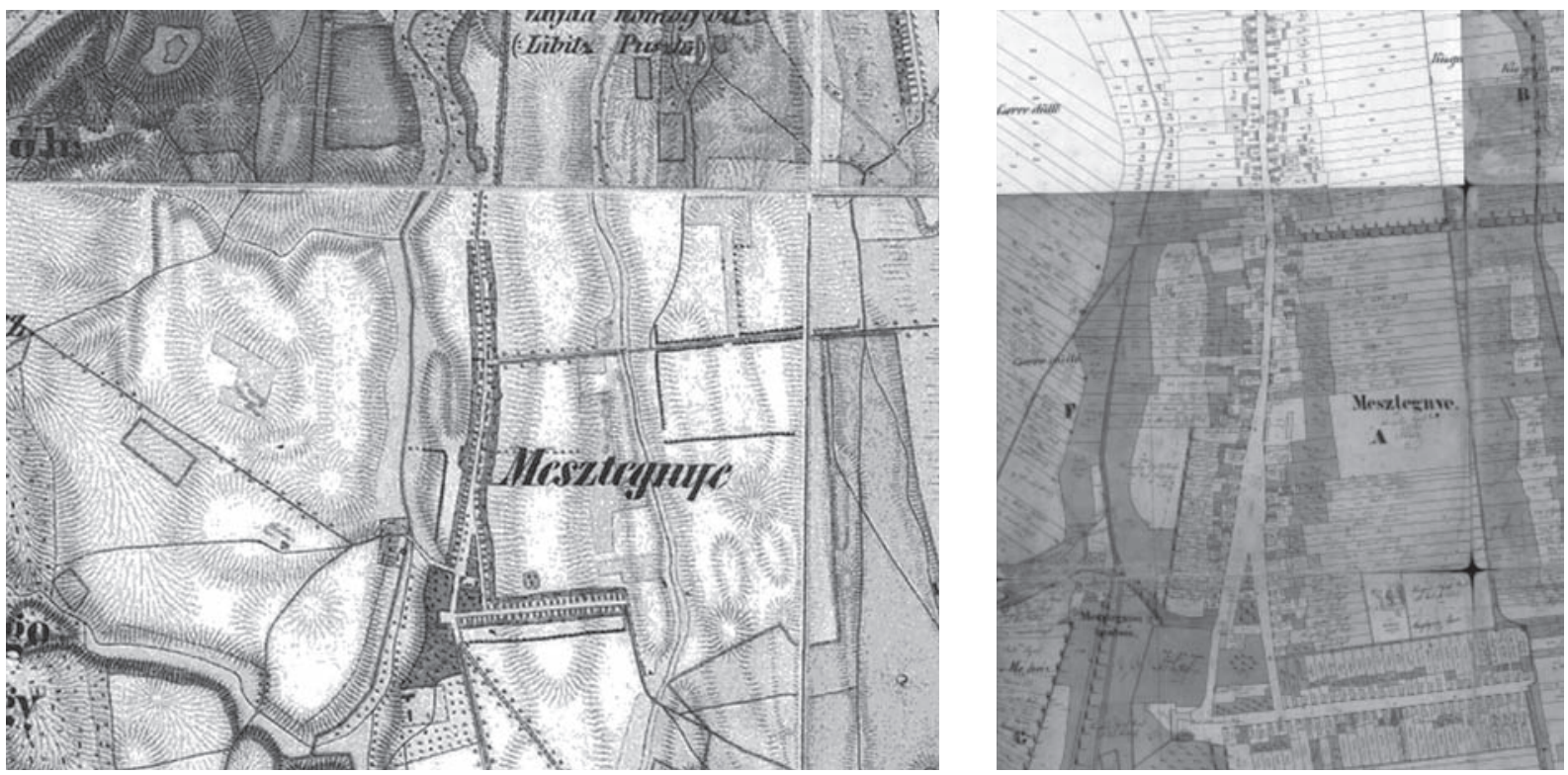

3-4. kép: Mesztegnyő belterülete a II. katonai felmérés és az 1859. kataszteri térkép alapján

A ferences kolostor eredetileg teljes quadrumként épült ki (Id. I. katonai felmérés), igaz, hogy a templom északi oldalán csak egy 2,5 méter széles folyosóval. Az épületegyüttesről egy 1854-ből származó, Koller János plébános által a mesztegnyői plébánia történetéről szóló emlékirat így emlékezett meg: „templom homlokzata áll napkeletnek, hátulsó része nyugotnak, másik északra, harmadik keletnek, negyedik ragasztaték a templom falához, mi folyosóul szolgálva kényelmes összefüggést adott az egésznek."21
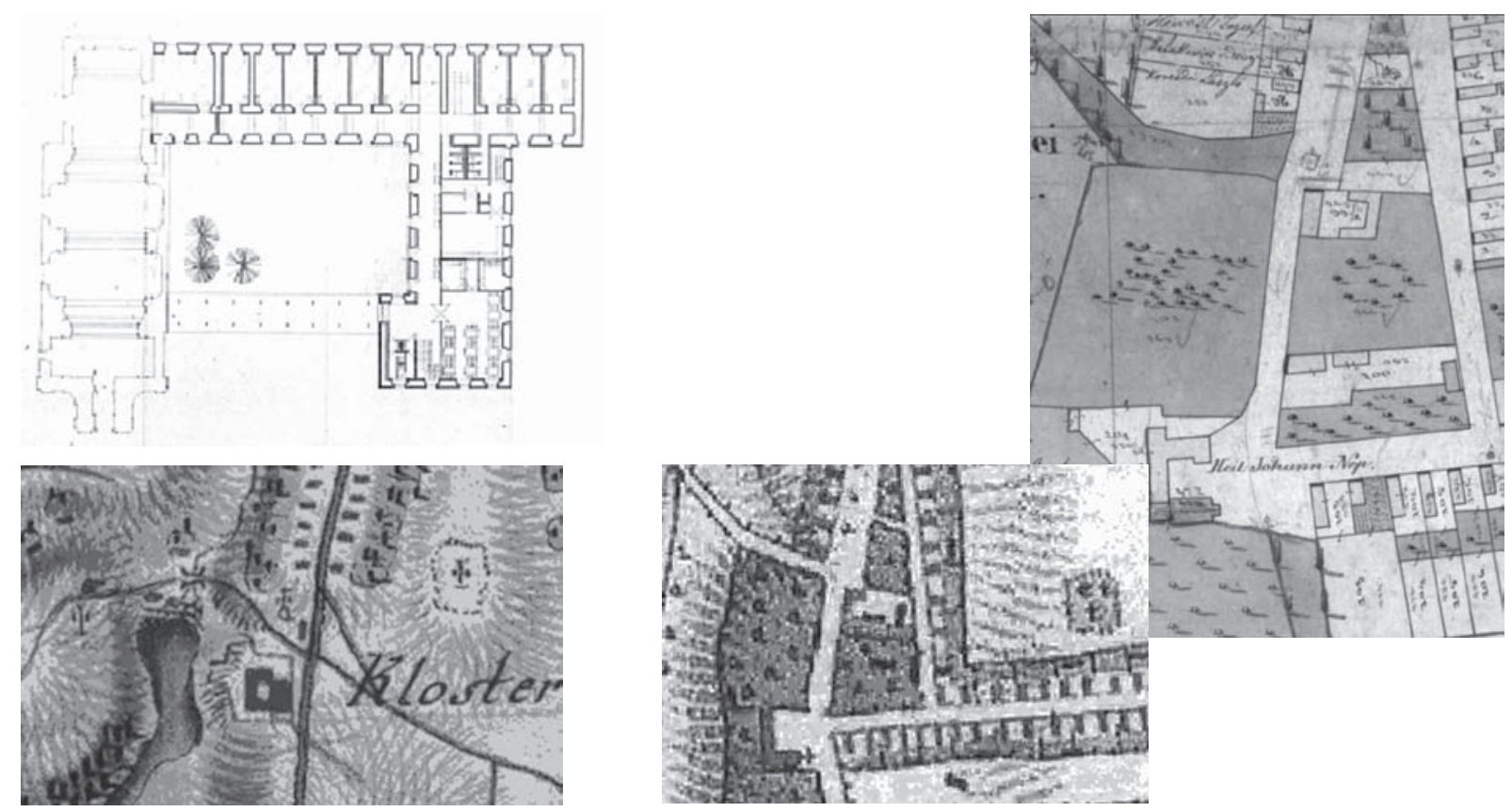

5-8. kép: A kolostor alaprajza és ábrázolása történelmi térképeinken

19 Rupp III. 279.

20 Vizy 2012.

21 G. Jáger 2007. 
A folyosót és a keleti szárnyat 1815-ben bontották el. A szerzetesrendek feloszlatásával a kolostorban katonai kórház létesült, majd 1806 után, amikor a Hunyadi család visszaszerezte, posztógyártók, árokmetszők és zsellérek lakták. 1872-ben a Szent Vince rend apácái költöztek az épületbe, és 1948-ig leányneveldeként, óvodaként tartották fenn. A kolostortemplom szentélyét eredetileg 2 méterrel magasabbra tervezték, de az 1772. évi kifestés előtt átépítették, az északi ablakokat befalazták, a déli ablakokat hegedűablakká alakították át. A templom főoltárán kívül 4 mellékoltárral rendelkezett, és Dorfmeister freskói díszítették, melyek közül több megsérült a II. világháború alatt. A templom bejáratához közel, a déli oldalon a szerzetesi kriptát helyezték el, míg a főoltár felöli kriptarészen a Hunyadiak temetkeztek. A templom szentélyéhez északról csatlakozott a sekrestye, amely mellett raktárszoba és az uradalmi levéltár kapott helyet.
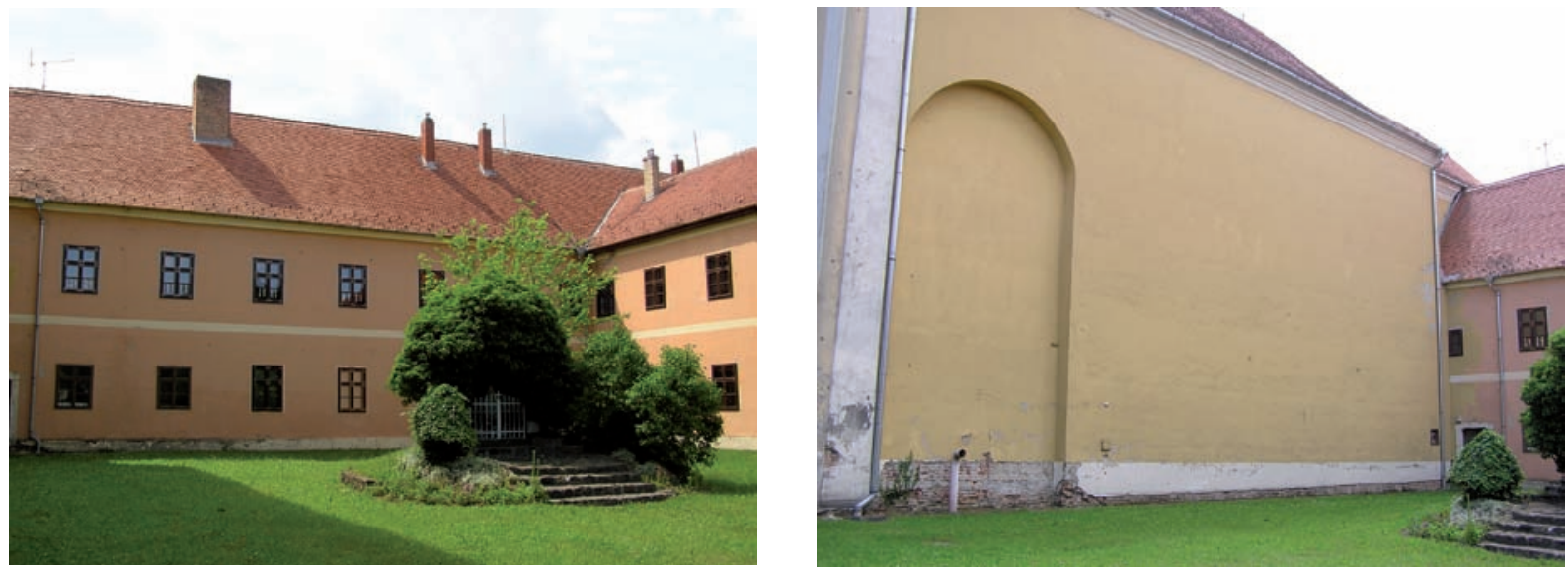

9-10. kép: A megmaradt nyugati és északi kolostorszárny és az elbontott keleti szárny lenyomata

\section{Mesztegnyő Árpád-kori és középkori régészeti lelöhelyei}

A településen a múzeumi adattár tanúsága szerint Árpád-kori temetőt találtak. ${ }^{22} \mathrm{~A}$ ferences kolostortemplom, az általános iskola és az óvoda épületeivel határolt plató a középkori erődített kolostor nyomait őrzi. Az erődítés maradványa leginkább a Malom köz déli oldalán, a játszótér melletti 4 méter mély és 15 méter széles ároknál figyelhető meg, amely a vízmúnél a Sári-csatorna patakvölgyébe torkollik, ami nyugat felől határolta a kiemelkedést.
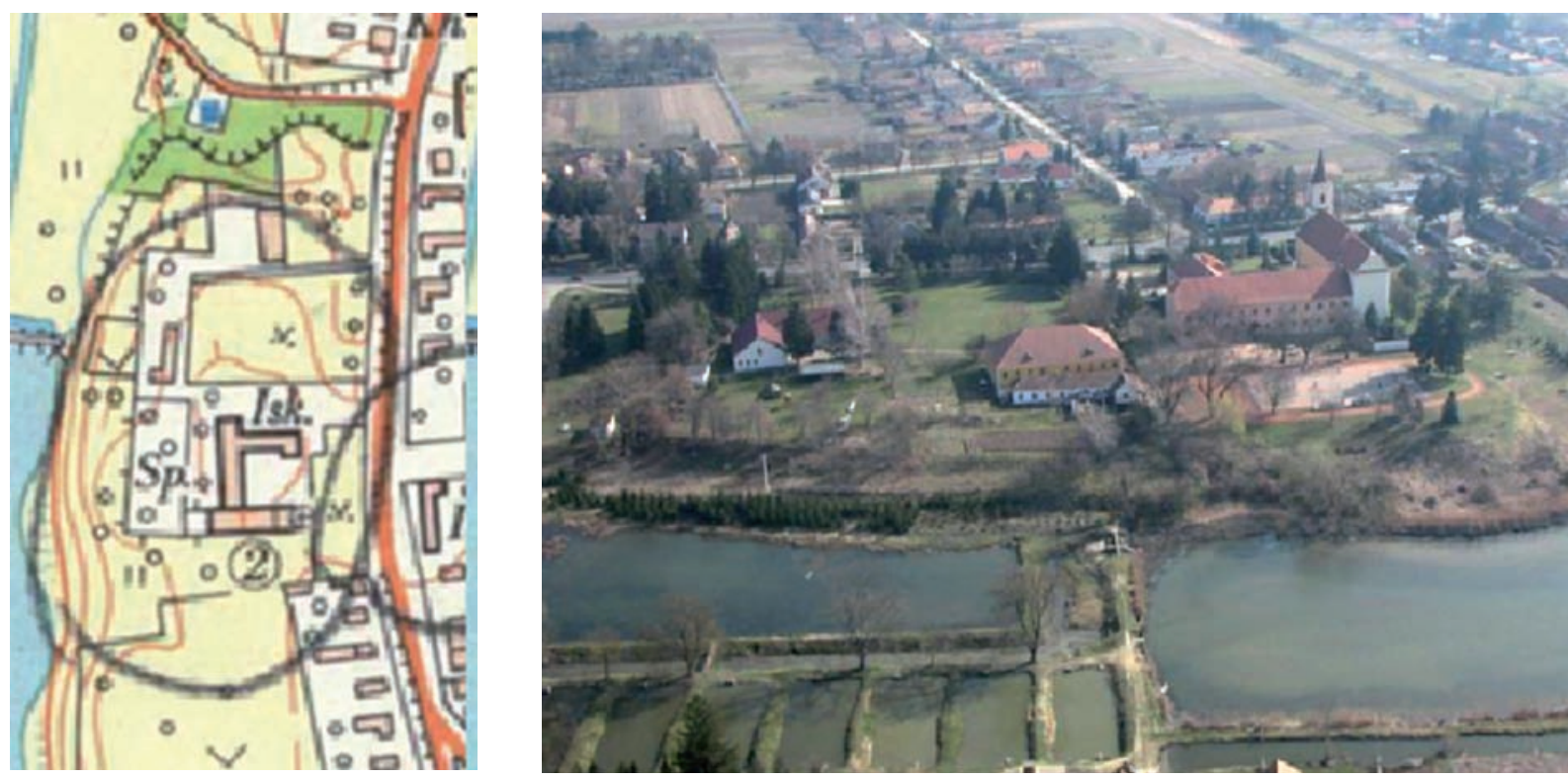

11-12. kép: A plató a ferences kolostorral a 10.000-es térképen és Tóth Géza légifotóján

22 Draveczky - Sági - Takács 1964. 35. 

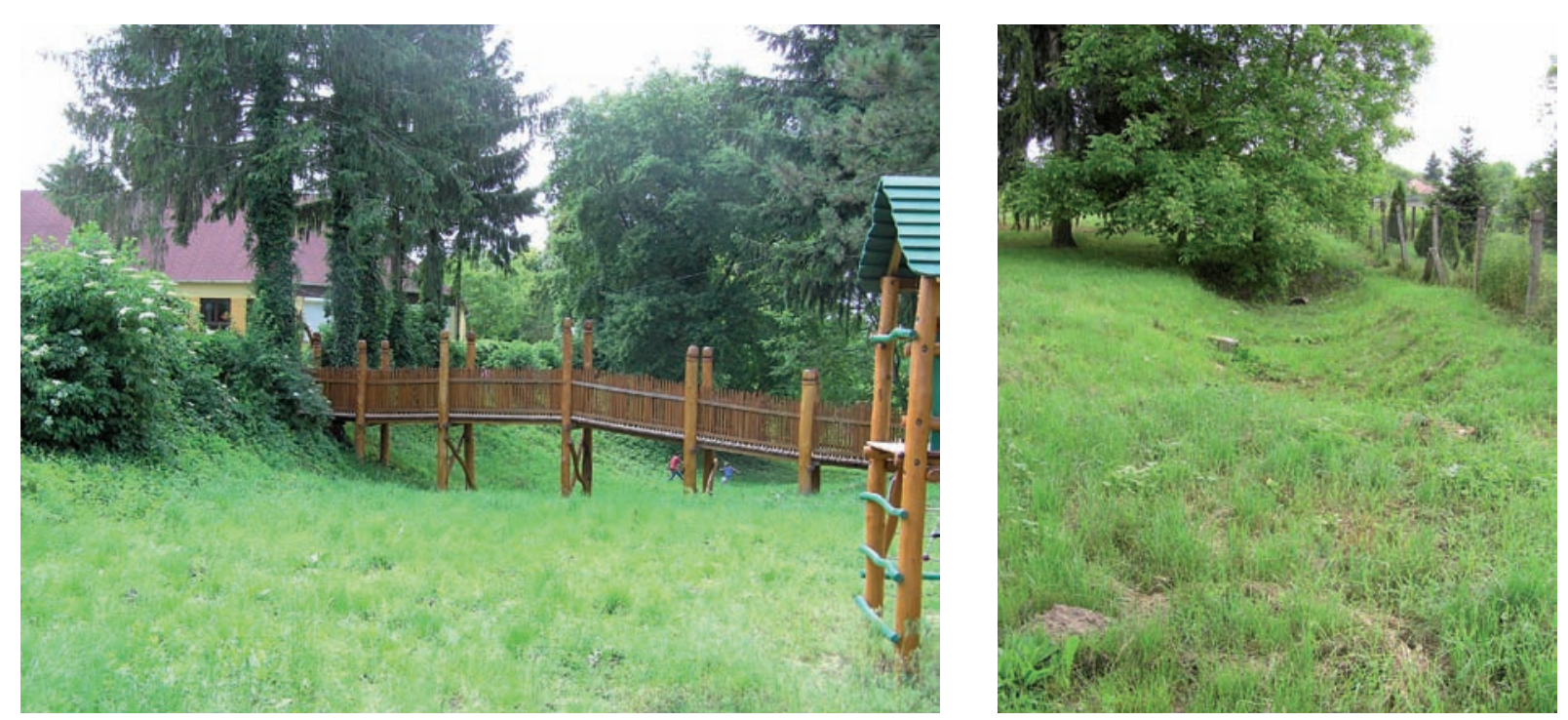

13-14. kép: Az erődítés megmaradt nyomai a helyszínen (a játszótér és a templom mellett)

A belterület nyugati határán a Sári-csatornából létesült halastó mindkét partján, a 68-as út két oldalán Árpád-kori és középkori településnyomok figyelhetők meg a Sós-gáti dűlőig terjedően.

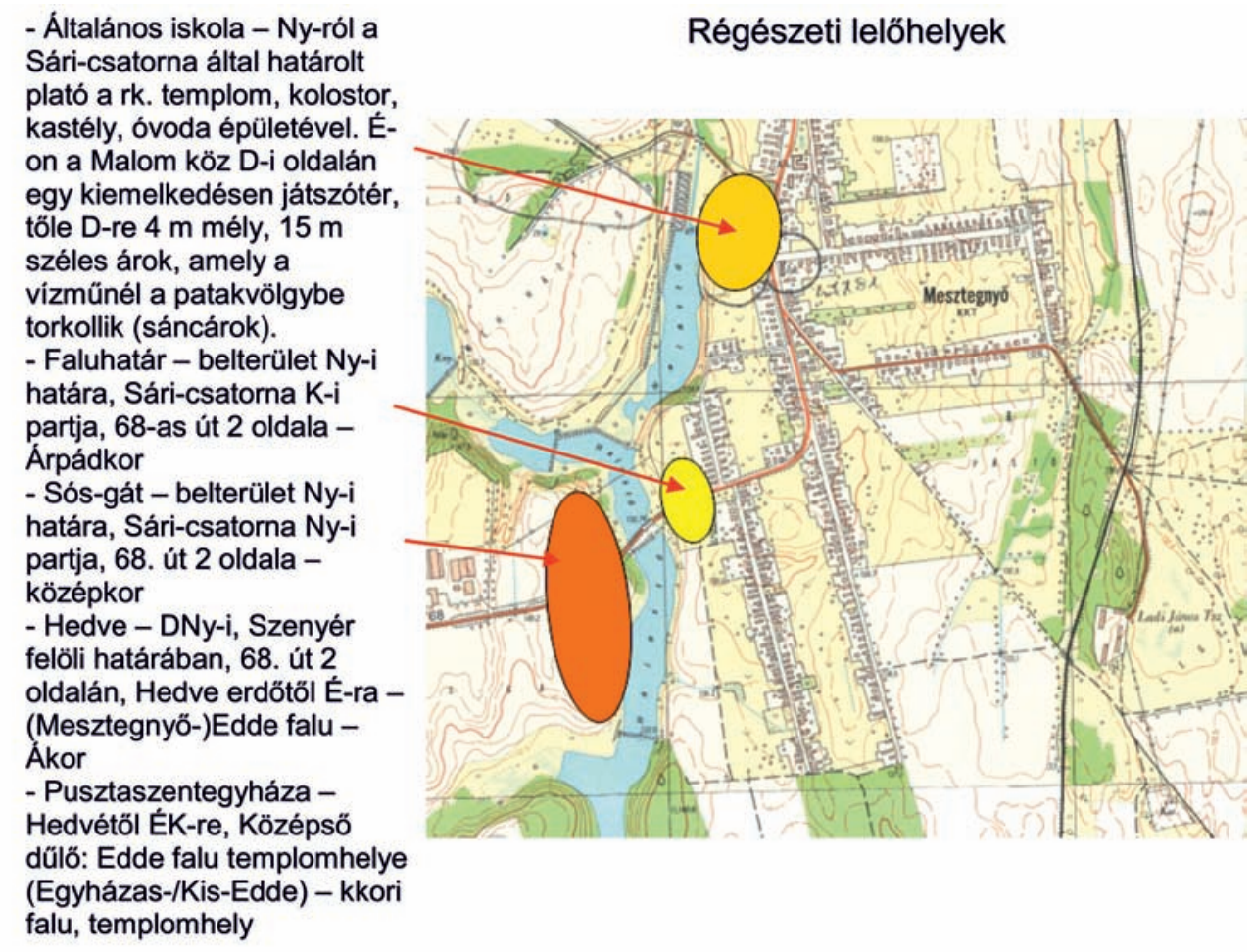

15. kép: Régészeti lelöhelyek a településen

Mesztegnyő délnyugati, szenyéri határában, a 68-as út két oldalán, Hedve erdőtől északra Árpád-kori településnyomok a valamikori (Mesztegnyő-)Edde nevű falura utalnak, melynek temploma ettől északkeletre, a Középső-dűlőben (Pusztaszentegyháza) állt (Egyházas-Edde), ahonnan gyűrűk és dénárok is származnak.23

23 RRM RA III/14/4, Itsz. 2240, Papp - Végh 1974. 100/122. 309. 


\section{A történeti településszerkezet nyomai}

A háromszög alakú tér (Szabadság tér) északi részén észlelhető orsó alakú kiszélesedés a régi piactér nyoma, míg ettől délre a majorság épületei és kútja volt megfigyelhető a 19. századi térképeken. A korábbi központi területen a telkek nagyok, de eltérő nagyságúak voltak, és még ma is sok helyen észlelhető az utcával párhuzamos beépítés, ami a 19. század közepétől a parasztpolgári épületek jellemzője volt. Az utca nyomvonalán is látszik, hogy nem nyílegyenesen, vonalzóval húzták, hanem követi a domborzat, illetve a történelmileg kialakult telkek változásait. Érdekes a temető elhelyezkedése, amelyet már az I. katonai felmérés is itt ábrázol, azonban sem a múzeumi adattár, sem a helybeliek nem tudnak a területen korábbi temetkezésre vagy templomra utaló nyomokról. A középkori plébániatemplomot azonban vagy itt, vagy az I. katonai felmérés által még jelölt, a kolostortól északra ábrázolt templom helyén valószínűsíthetjük. ${ }^{24}$

A központ feltehetően már a középkorban is kolostor szomszédságában lehetett, amit a régészeti lelöhelyek elhelyezkedése is alátámaszt. Koller János plébános tanúsága szerint a kolostor „egy emelkedett domb, melly hányt föld, és épületrészekből áll, miről a most élő öregek csak annyit bizonyítanak, hogy körében hajdan temetö volt.".25
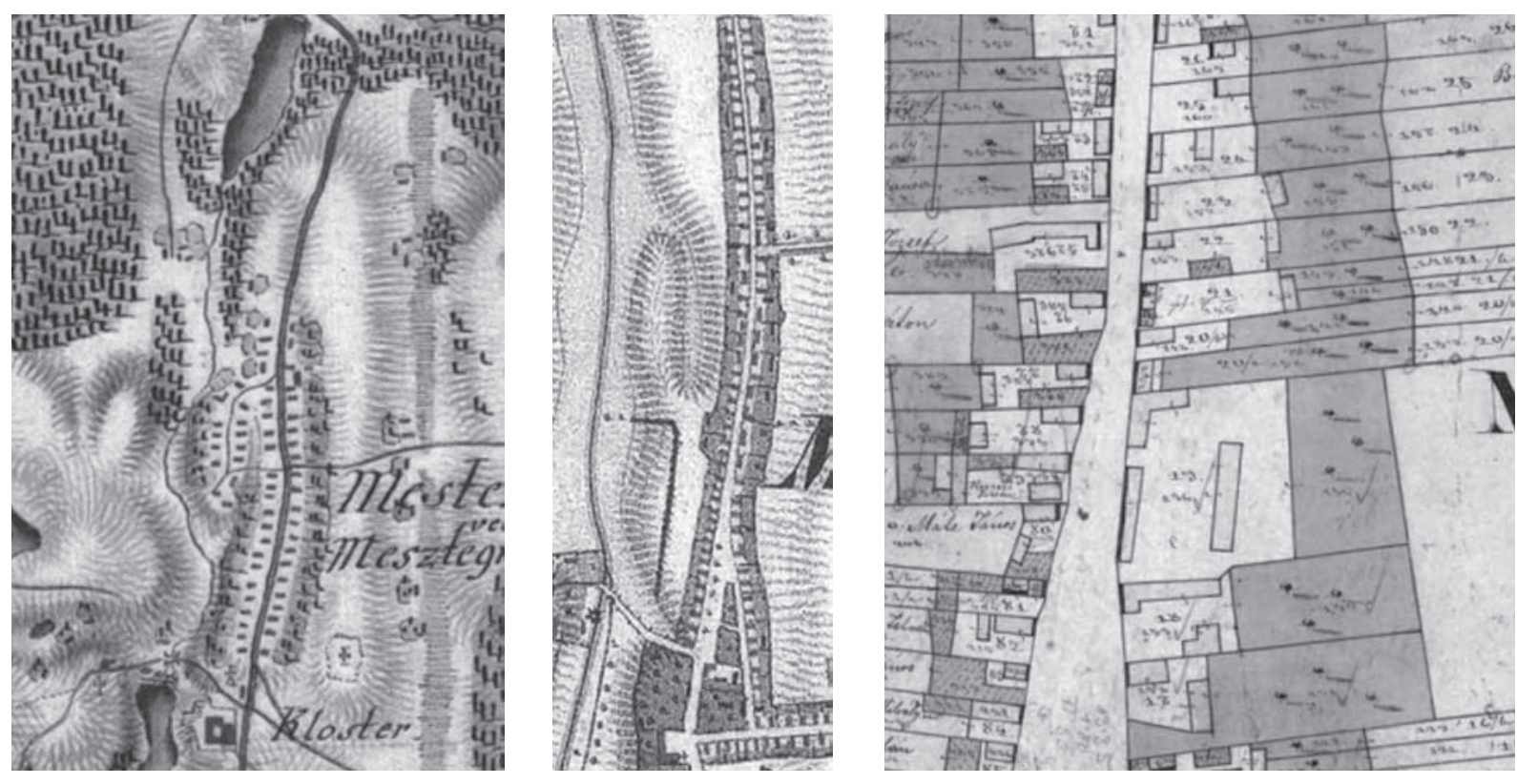

16-18. kép: A központi terület a három térképen

Az I. katonai felmérésen a Fő utcával párhuzamosan, attól keletre még halványan észlelhető egy utca megléte, melynek vonalát a még megmaradt telkek jelölték ki. A régészeti lelőhelyek tanúsága alapján a középkori település déli irányban is nagyobb kiterjedésủ lehetett, amely magyarázza a relatíve magas lélekszámot a 15. században. A 19. századtól történő betelepítések során, típustervek alapján egyenes vonalvezetésű utakat és az egységes szalagtelkeken az utcára merőleges beépítést lehet nyomon követni. A korábbi utak nyomvonalvezetését - amennyiben erre lehetőség nyílt - utólag kiegyenesítették (pl. a Fő u. északi részén keletre húzódó út), és csak a korábban már beépített településrészeken maradt meg az eredeti nyomvonalvezetés.

Miután a belterületi majorsági területek nem bizonyultak elégségesnek, a Hunyadiak létrehozták a település déli végében az ún. Pajtáskertet, ahol bognár és kovácsműhely is létesült, és kiépítették a Malomárkot is. Ettől délre vadaskertet tartottak fenn.

\section{Összegzés}

Az összegyűjtött adatok szerint valószínúnek tűnik, hogy a középkori oppidum kiterjedése mind keleti és déli irányban jelentősen meghaladta a 18-19. századi méreteket, sőt az I. katonai felmérés alapján északnyugat felé is találhatunk egy kisebb, valószínűleg még középkori eredetủ településrészletet, amely a ké-

24 Amennyiben ez a templom nem azonosítható a 18. század elején emelt épülettel.

25 G. Jáger 2007. 


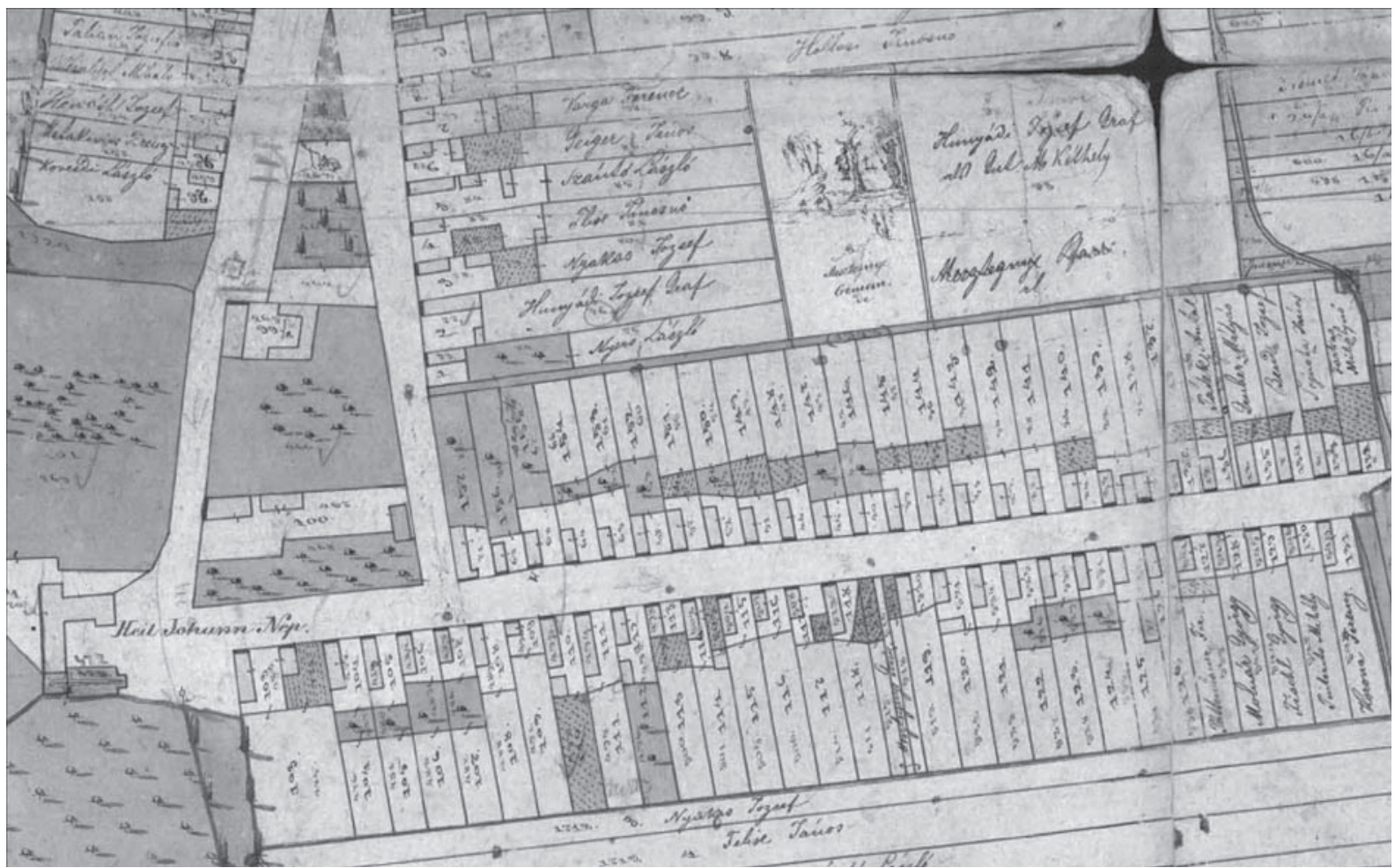

19. kép: Telepített utcakép (Cseh u.)

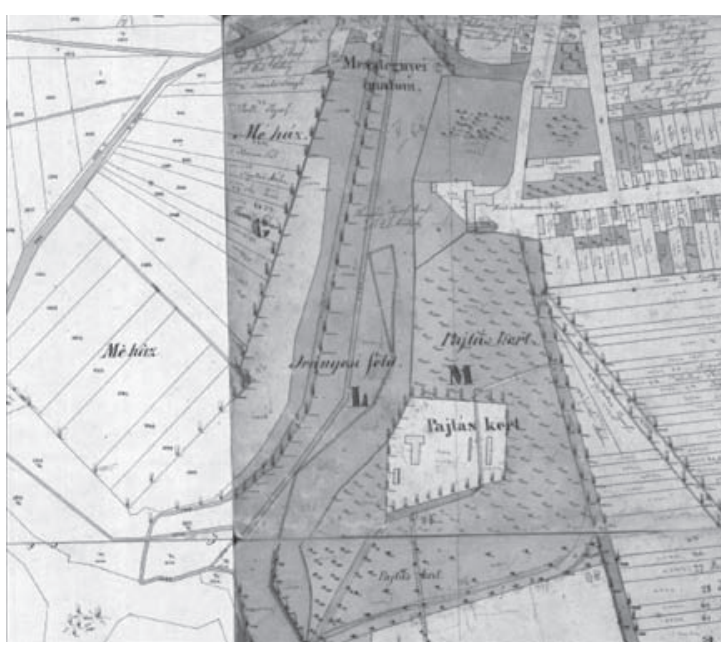

20. kép: A malom és a Pajtáskert

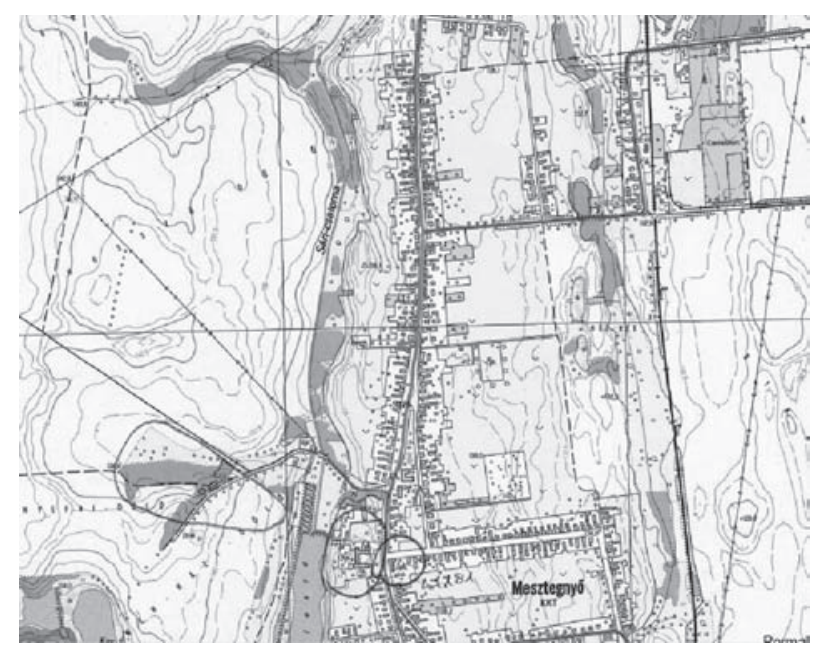

21. kép: A település mai állapota

sőbbiekben elsorvadt. A történelmi településszerkezetre utaló nyomok a mai Szabadság tér és Vörösmarty u. mentén maradtak fenn, ezek további védelmét, megőrzését mindenképp szem előtt kell tartani. Ugyancsak fontos a kolostorterülettől északra, a malom felé kiinduló út (Malom köz) nyomvonalának megóvása, amelynek eredete valószínűleg még a középkorra tehető. ${ }^{26}$ Megőrzendő a háromszög alakú teresedés illetve annak orsó alakú kiszélesedése, még akkor is, ha ennek középkori eredetét ásatások nélkül egyelőre nem tudjuk bizonyítani.

26 Tájadottságok alapján gyanítható, hogy már a domonkos kolostor idejében is állhatott malom a helyszínen. 
A településrendezési tervek készítésekor, a történeti településrészek lehatárolása érdekében a történeti településszerkezet megismerése döntő fontosságú. Az írott források mellett a településszerkezet rekonstrukciója érdekében a történeti térképek tanúsága, valamint a máig megmaradt szerkezeti elemek (utcaszerkezet és vonalvezetés, telekosztás, beépítési mód) egybegyűjtésére is nagy szükség van. Mint Mesztegnyő esetében is látni lehet, későbbi beépítések sokszor értelmezhetetlen, illogikus struktúrát erőltettek a meglévő rendszerre. ${ }^{27}$ A telkenkénti/épületenkénti karaktervizsgálatból kiinduló építésszabályozás alkalmazása, a község szövetébe keletkezett sebek orvoslása, foghíjak beépítése csak akkor valósulhat meg kielégítő módon, ha a meglévő térbeli rendszert, beépítési arányokat, épületek léptékét és anyagát tiszteletben tartja.

\section{The changes of medieval settlement structure in Mesztegnyő}

\section{CSILLA ARADI}

New categories appearing in contemporary legislation provide a more significant protection for historical town-, and city centers. With the cognition of historical structures in a given settlement, the still existing street network and land division can be better preserved.

Mesztegnyő is first mentioned in 1329, but it is presumably older as in 1333 its parish is already functioning. In 1436 it is a deanery seat, while in 1466 the town is a market place of national significance. During the 14th century. It is the seat of the Szerecsen family, while later on the Gordovai Fancs family resides here. In 1476 according to the supplication of Szentey György, Dominican friars appear in Mesztegnyö, who practiced spiritual care as well. According to the Canonica Visitatio dating from 1743 two ruined churches stood near to the 18th century. Settlement, one of which was the parish, while the other was the cloister church, which was used by the landlord for building material for the newly found Franciscan friary.

By the use of 18-19th century historical maps and with the help of archaeological evidence the extension of the medieval settlement can be well traced. Some parts of the historical settlement structure together with the street network and land division were preserved while other settlement parts disappeared together with the opening of new streets with regular land division in the 19th century.

27 Vigyázni kell arra, hogy falusias környezetben ne igyekezzenek helytelen értelemben felfogott városias képet adni. 


\section{Irodalom}

Bándi Zs. 1986.: A szakácsi pálos kolostor középkori oklevelei. Somogy Megye Múltjából 17. 27-66.

Borovszky S. - Csánki D. 1914.: Magyarország vármegyéi és városai. Somogy vármegye. Budapest

Borsa I. 1996.: A somogyi konvent oklevelei az Országos Levéltárban. 1301-1330. Somogy Megye Múltjából 27. 49-68.

Békefi R. 1907.: A Balaton környékének egyházai és várai a középkorban. In.: Lóczy Lajos (Szerk.): A Balaton tudományos tanulmányozásának eredményei 1904-1920.3. Budapest

Csánki D. 1894.: Magyarország történelmi földrajza a Hunyadyak korában II. Budapest

G. Jáger M. 2007.: Mesztegnyő. Száz magyar falu könyvesháza. http://www.sulinet.hu/oroksegtar/data/telepulesek_ ertekei/100_falu/Mesztegnyo/pages/000_konyveszeti_adatok.htm

Harsányi A. 1938.: A domonkosrend Magyarországon a reformáció előtt. Debrecen

Kanyar J. 1991.: Kanyar József (Szerk.): Marcali története. Várostörténeti tanulmányok I. Marcali

Kubinyi A. 1989.: Mezővárosok egy városmentes tájon. A középkori Délnyugat-Magyarország. A Tapolcai Városi Múzeum Közleményei 1.319-332.

Lángi J. 1995.: A mesztegnyői ferences templom falképei és berendezése. Műemlékvédelmi Szemle 1995/1-2. 229 -264.

Lukcsics P. 1938.: XV. századi pápák oklevelei II. Budapest

Mon. Rom.: Fraknói Vilmos - Lukcsics József (Szerk.): Monumenta Romana Episcopatus Vespremiensis I-IV. 1896-1907., Budapest

Romhányi B. F. 2000.: Kolostorok és társaskáptalanok a középkori Magyarországon. Budapest

RRM RA: Rippl-Rónai Múzeum Régészeti Adattár

Rupp I-III.: Rupp Jakab: Magyarország helyrajzi története fő tekintettel az egyházi intézményekre, vagyis a nevezetesb városok, helységek és azokban létezett egyházi intézetek püspökmegyék szerint rendezve I-III. 1870-1876., Pest

Draveczky B. - Sági K. - Takács Gy. 1964.: A Somogy megyei múzeumok régészeti adattára. Somogyi Múzeum 2. Kaposvár Papp L. - Végh J. 1974.: Papp László - Végh József (Szerk.): Somogy megye földrajzi nevei. Budapest

Vizy M. 2012.: A mesztegnyői kolostor műemléki vizsgálata (kézirat) 2012.

ZSO: Mályusz Elemér - Borsa Iván (Szerk.): Zsigmond-kori oklevéltár. I-V. 1951-1997., Budapest 